\title{
Development Of An Equipment For In Field Measuring of Traction Forces During Soil Tillage
}

\author{
Sorin STĂNILĂ \\ Department of Technical Science and Soil Science. University of Agricultural Sciences \\ and Veterinary Medicine Cluj-Napoca, Romania \\ * corresponding author: sorin.stanila@usamvcluj.ro \\ Bulletin USAMV series Agriculture 71(2)/2014 \\ Print ISSN 1843-5246; Electronic ISSN 1843-5386 \\ DOI 10.15835/buasvmcn-agr: 10573
}

\begin{abstract}
Knowing the values of traction forces is important for the optimization of constructive and working parameters for soil tillage tools. This optimization is referring to: reducing energy consumption, maximization of working capacity, reducing costs etc.

Equipment for in field measuring of traction forces during soil tillage was developed at Technical Sciences and Soil Sciences Department from the Faculty of Agriculture to measure and evaluate tractor and tillage tools' parameters. The measuring system has two steel frames and six force transducers which were calibrated for in field operations. This system will be able to measure the traction forces for different agricultural machines in different soil conditions up to $50 \mathrm{kN}$. After the calibration, it resulted linear calibration curves for forces transducers and those can be used to measure in field operations.
\end{abstract}

Keywords: force transducers, data acquisition, traction forces, soil tillage

\section{INTRODUCTION}

The traction forces can be determined theoretically with different relations (V.P. Goriacikin), or they can be measured in field with different implements (Ranta 2004, Molnar 2003, Scholtz 1966).

The traction forces of soil tillage machines depend on many parameters: the physical and mechanical soil parameters, working condition of tillage tools (working speed, working depth etc.) and constructive parameters of tillage tools (Gheres 2013, Molnar 2005).

Based on their researches, Larson, Lovely and Backhop have elaborated mathematical models to analyze the influences of different parameters on traction forces at soil tillage. (Ormenisan 2014). They recommend to tillage the soil when the agro technical conditions are favorable (reduced soil humidity) and the traction forces are reduced.

Knowing the values of traction forces is important for the optimization of constructive and working parameters for soil tillage systems. This optimization is referring to: reducing energy consumption, maximization of working capacity, reducing costs etc (Morar 2013, Rusu 2013).

The collective of Technical Sciences and Soil Sciences department, from the Faculty of Agriculture has developed a system for measuring traction forces of agricultural machines in field operation. This system will be able to measure the traction forces for different agricultural machines in different soil conditions up to $50 \mathrm{kN}$.

This paper presents how the system is made and methods for sensor calibration for forces measurement. The system will be capable of determining the value of longitudinal forces (Fx), vertical forces (Fz) and transversal forces (Fy).

\section{MATERIALS AND METHODS}

For measuring the traction forces, the system has two steel frames which are mounted between the tractor and the agricultural machine (Fig. 1) Those two frames are linked together by six HBM S2/S9 force transducers: three for longitudinal forces (1 and 2), two for vertical forces (3 and 

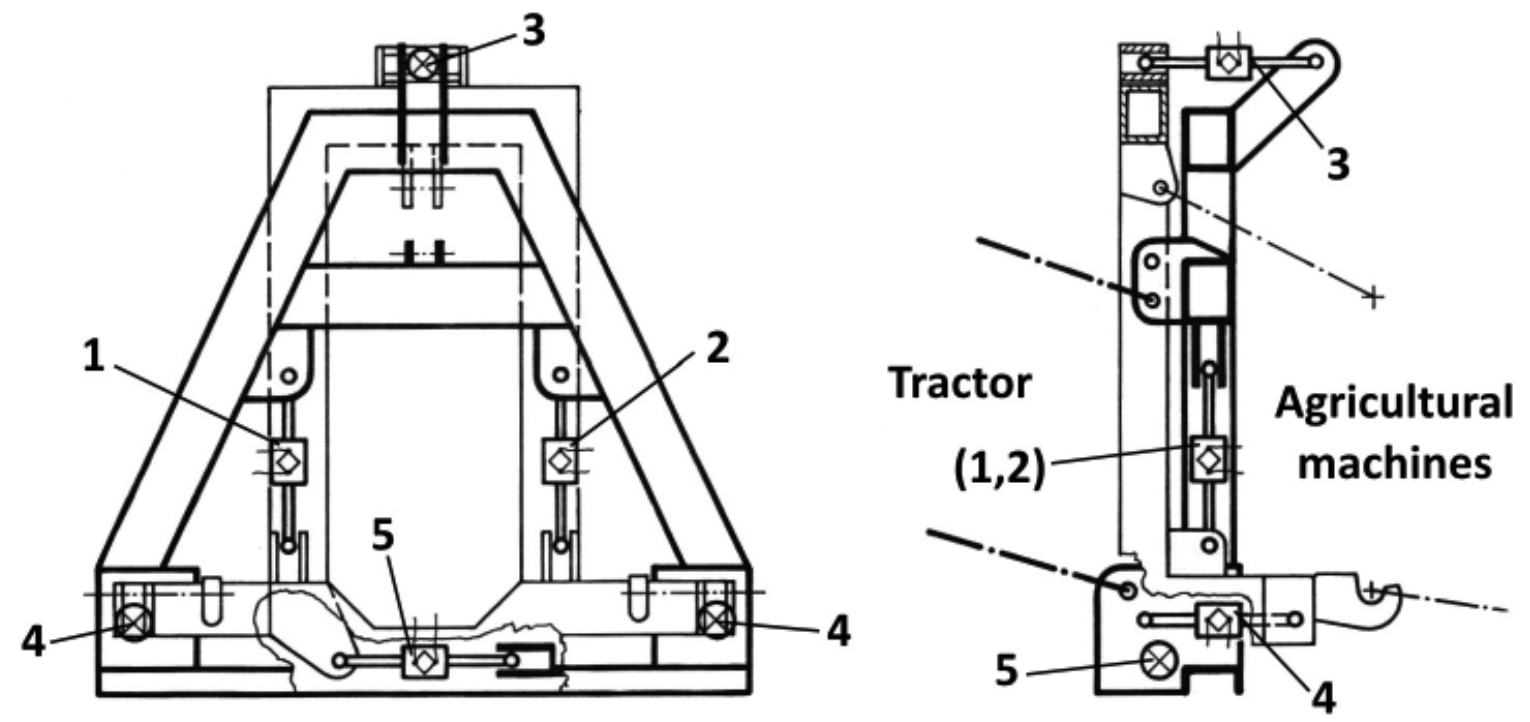

Fig. 1. Steel frames mounted between tractor and agricultural machine
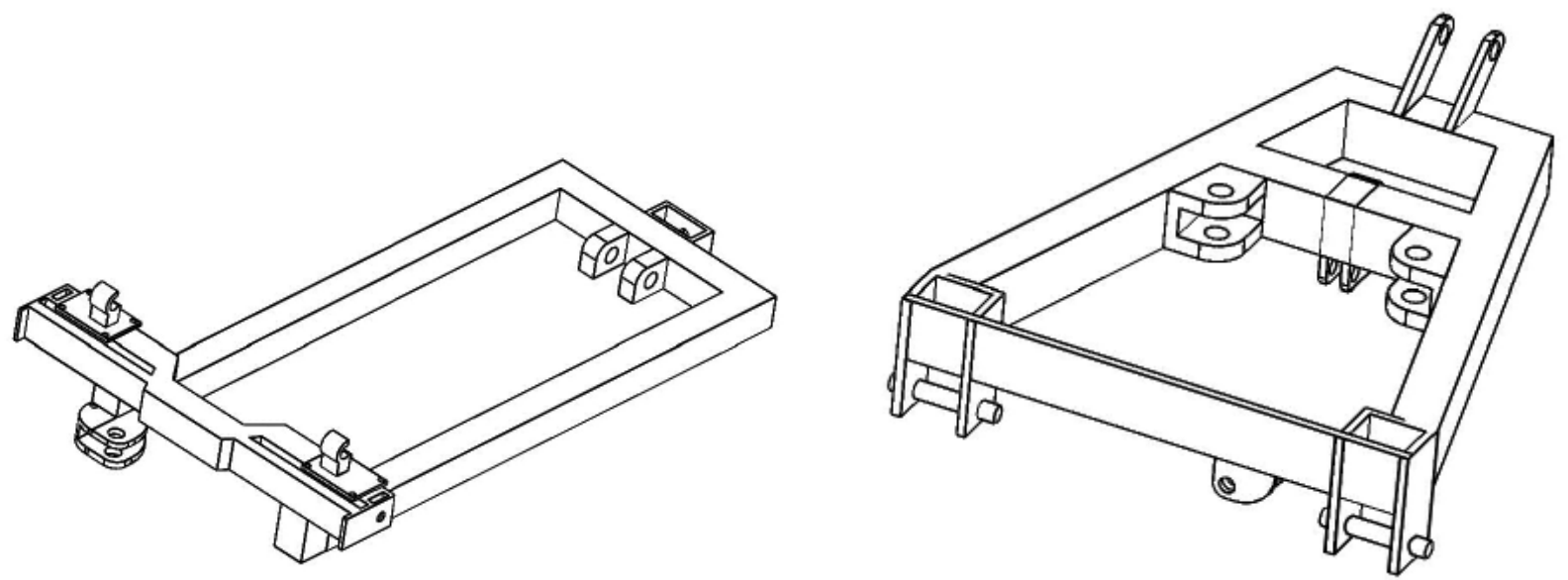

Fig. 2. The design of the steel frames drew in CAD software

4) and one (5) for transversal forces (rotation moment is created between two frames).

The frames were designed (shape and dimensions) at the Department of Technical Sciences and Soil Sciences from the Faculty of Agriculture (Fig. 2). One frame is mounted on the tractor with a 3 point hitch system and the other frame is mounted on the agricultural machine, also with a 3 point hitch system. The frames are linked together by force transducers which will measure the traction forces (pulling forces) needed to move the tillage through the soil.

We used six force transducers from the HBM-S2/S9 series which are suitable for measuring tensile and compressive forces (Fig. 3). They provide extremely accurate measurements of static and dynamic forces.

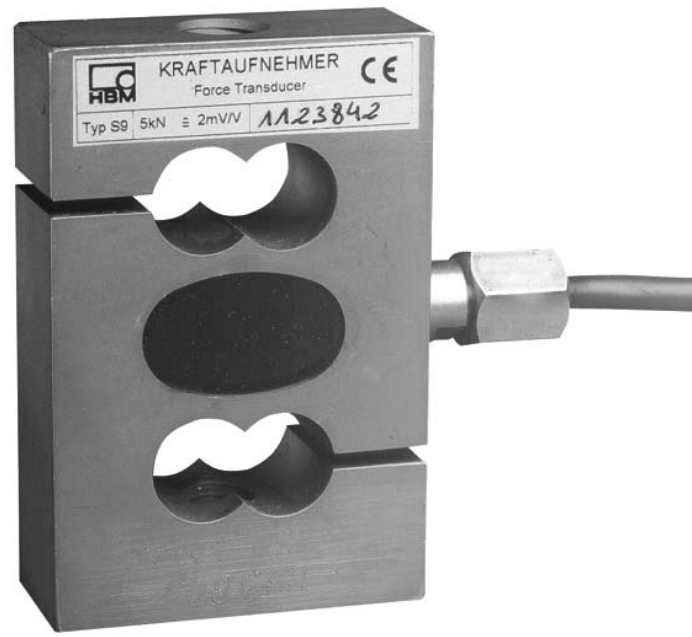

Fig. 3. Force transducer HBM-S2/S9 series 
All six force transducers are connected to a data acquisition device HBM-SPIDER8 which is an measuring system for PCs for electric measurement of mechanical variables such as strain, force, pressure, path, acceleration and for temperatures. All the signal conditioning - excitation for passive transducers and amplification, digitalization, computer interface and connection technology for a maximum of 8 channels - is combined in one housing.

All data collected during measuring was processed with software Catman Easy 2 (installed on a PC) which is the original acquisition, visualization and analysis software from HBM

\section{RESULTS AND DISCUSSION}

The measuring system with two frames was developed at the Department of Technical Sciences from the Faculty of Agriculture, regarding shape, size and materials. The execution of frames will be made in collaboration with SC Tehnofavorit Bonţida SRL. The size of the frames was established to fit a wide range of tractors and agricultural machines with 3 different point hitch sizes.

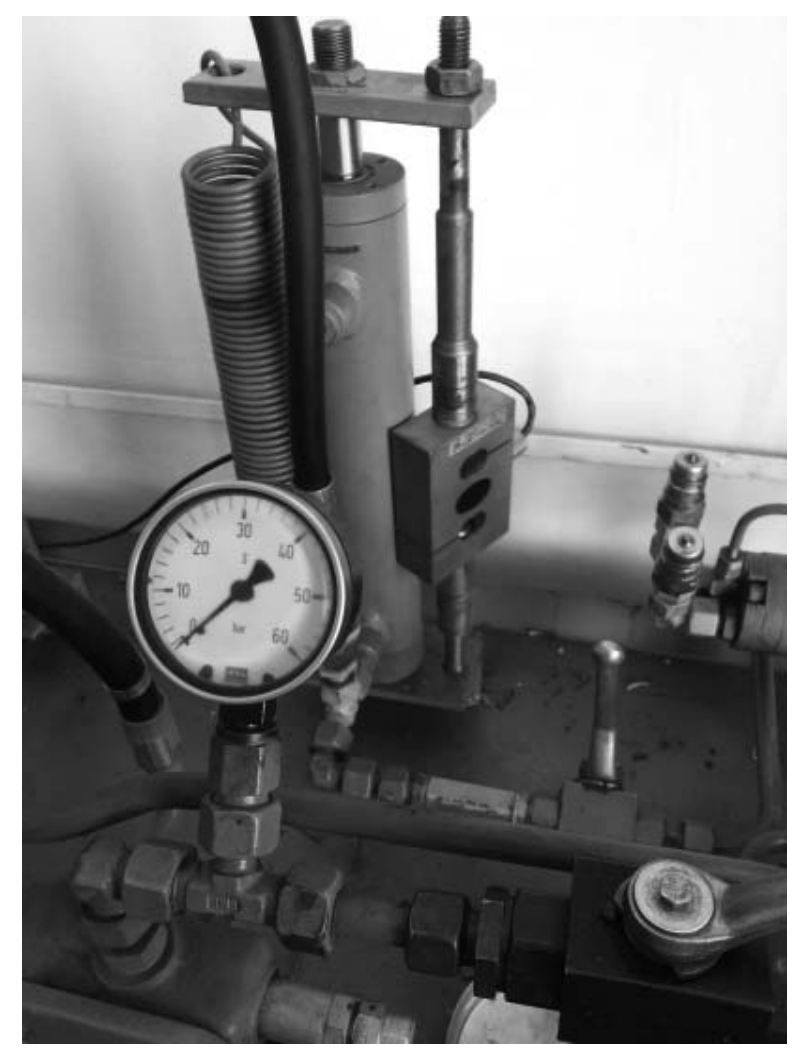

Fig. 4. Hydraulic stand
For calibrating the force transducers we used a hydraulic stand from the Technical Sciences and Soil Sciences department (Fig. 4). Each force transducer was mounted on a stand, tensioned and compressed to measure the forces range (Fig. 5).

In this paper there are presented the results of calibration for two force transducers. In figure 6 the variation of measured traction forces $(\mathrm{kN})$ in time (s) for those two transducers is displayed.

During transducers' loading, the oil pressure in the hydraulic cylinder, indicated by oil gauge, was permanently written in order to establish a correlation between the values of forces and oil pressure.

To chart the calibration curves for force transducers the values of the forces according to oil pressure indicated by oil gauge were represented. (Fig. 7 and Fig. 8)

By analyzing those two charts, a linear dependence between traction forces and oil pressure can be observed. Because of our hydraulic stand limitation, it was possible to apply a maximum pressure of 60 bar. In the $(18-60)$ bar range of pressure, the first transducer was loaded with

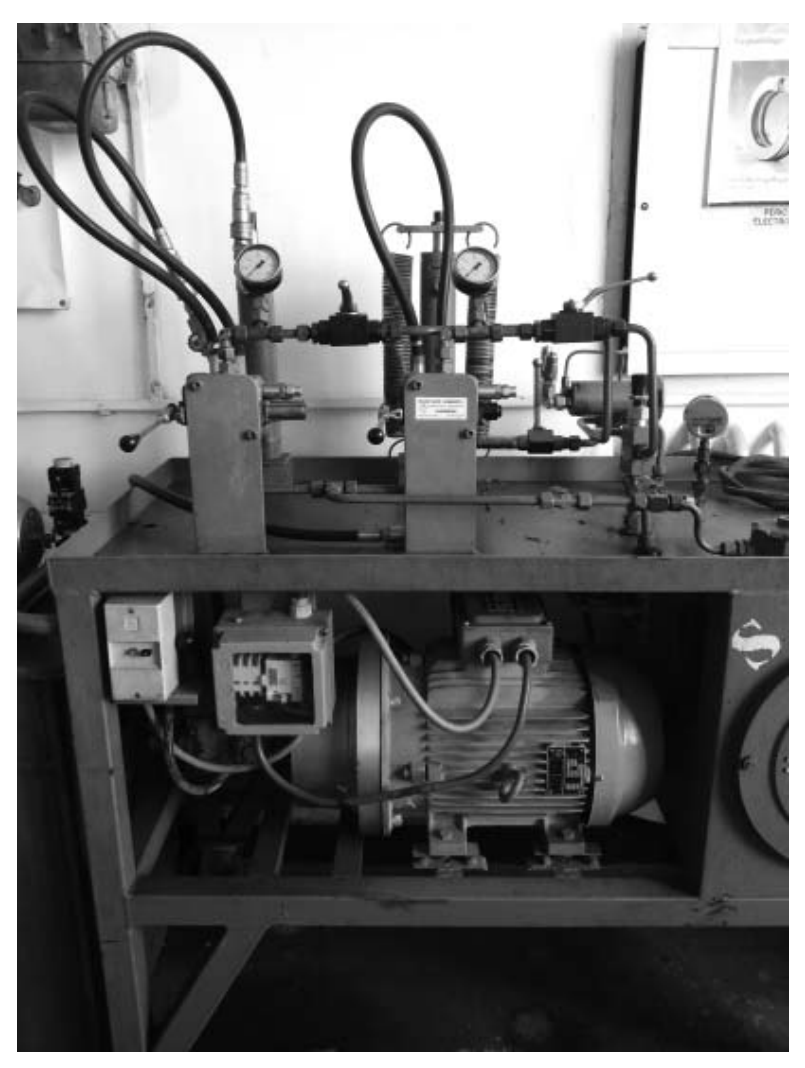

Fig. 5. Force transducer mounted on stand 


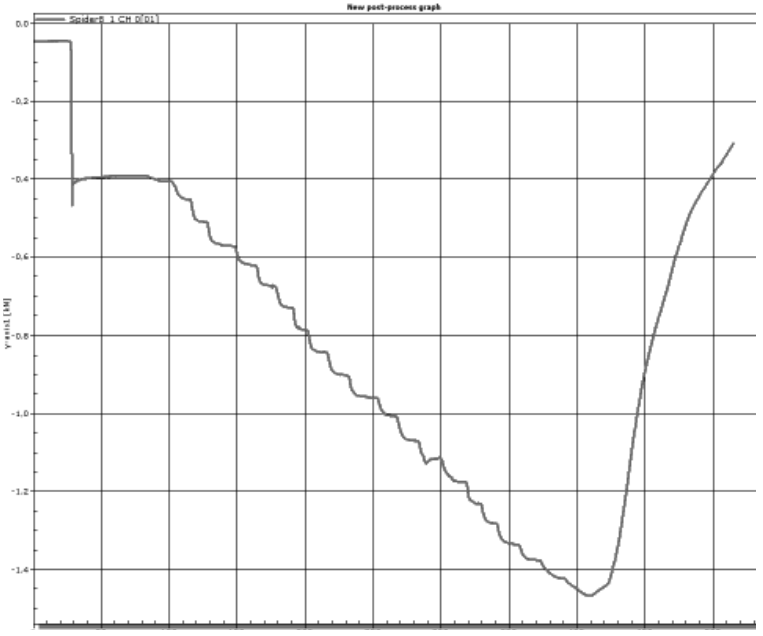

a. Force transducer 1

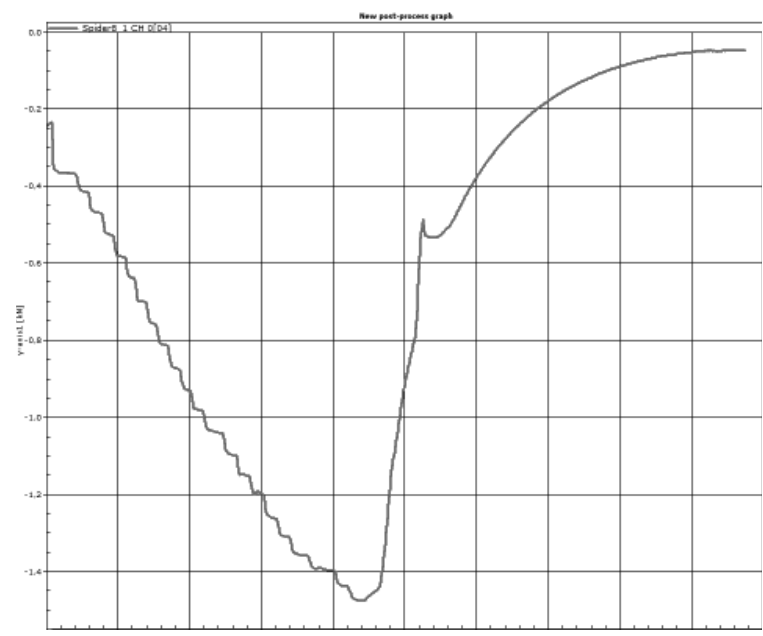

b. Force transducer 1

Fig. 6. Variation of traction forces in time

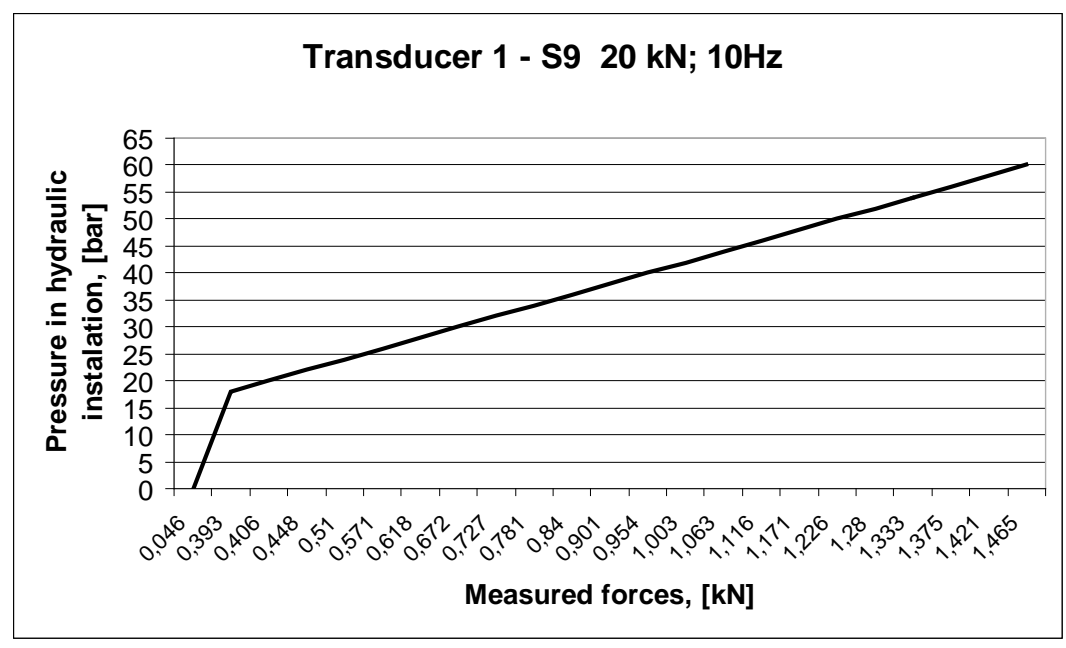

Fig. 7. Calibration curve for transducer 1

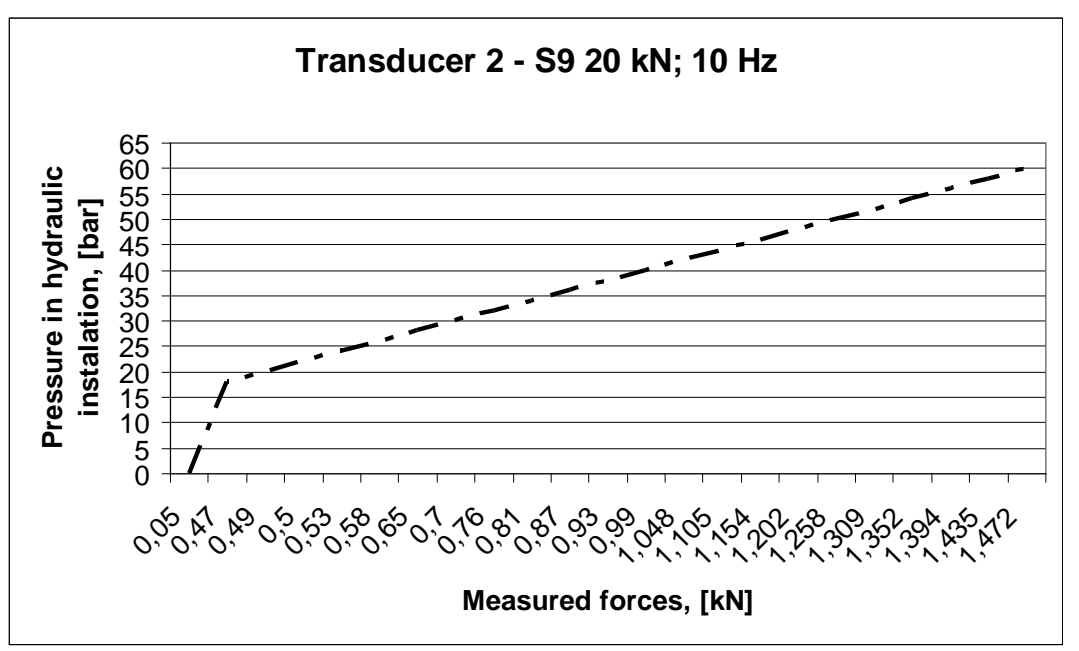

Fig. 8. Calibration curve for transducer 2 
forces between 0,389 $\mathrm{kN}$ and 1,46 kN and the second transducer with forces between $0,47 \mathrm{kN}$ and $1,47 \mathrm{kN}$.

After this calibration, it resulted that all forces transducers respect the manufacturer's prescriptions and can be used to measure in field operations.

\section{CONCLUSION}

Equipment for in field measuring of traction forces during soil tillage was developed at the Technical Sciences and Soil Sciences Department from the Faculty of Agriculture to measure and evaluate tractor and tillage tools' parameters. The measuring system has two steel frames and six force transducers which were calibrated for in field operations. This system will be able to measure the traction forces for different agricultural machines in different soil conditions up to $50 \mathrm{kN}$. After the calibration, it resulted linear calibration curves for all forces transducers and those can be used to measure in field operations.

\section{REFERENCES}

1. Gheres M. I., M. Gheres, (2013), Research on determination of interaction forces tools - soil, In: The 7th International Symposium "Soil Minimum Tillage Systems", USAMV Cluj - Napoca, Proenvironment, Vol. 6, Nr. 14, p. 262-270, ISSN 2066-1363.

2. Molnar, A., Köller, K., Roş, V. (2005), Considerations regarding soil compaction by agricultural machines,
Simpozionul cu participare internațională „Agricultura durabilă - agricultura viitorului, Craiova;

3. Molnar, A., Roș, V. (2003), Cercetări privind posibilitățile de deplasare a agregatelor agricole în lucru, în vederea reducerii compactării solurilor agricole, Zilele Academice Timișene ediţia a VIII-a, Simpozion „Omul și Mediul”, organizat de Academia Română - Filiala Timişoara şi Universitatea „Politehnica” Timișoara, Editura Mirton, 22 mai 2003, Timişoara;

4. Moraru Paula Ioana, Teodor Rusu, (2013), No-tillage and minimum tillage systems with reduced energy consumption and soil conservation in the hilly areas of Romania., 2013. Journal of Food, Agriculture \& Environment, Vol. 11, Issue 2/2013, pages 1227-1231, Section Agriculture, pISSN: 1459-0255, eISSN: 14590263, WFL Publisher Science and Technology, Helsinki, Finlanda.

5. Ormenișan A.N., (2014), Cercetări teoretice și experimentale privind influența sistemelor de reglare automata ale mecanismelor de suspendare ale tractoarelor asupra dinamicii și energeticii agregatelor de arat, rezumat teza de doctorat, Univ. Transilvania Brasov;

6. Ranta Ov., K. Koller, V. Ros , I. Drocaș, Ov. Marian, (2004), Study regarding the forces that occurs in a notill technology process in relation with geometrical parameters of the coulter discs, Buletinul USAMV-CN, 60/2004(-) ISSN 1454-2382;

7. Rusu Teodor, Ioan Pacurar, Marcel Dîrja, Horea Mihai Pacurar, Ioan Oroian, Smaranda Adina Cosma, Marinela Ghereș, (2013). Effect of tillage systems on soil properties, humus and water conservation,Agricultural Sciences, Vol. 4, No. 5B, May 2013, p. 35-40. ISSN 2156-8553;

8. Scholtz D.C., (1966), A three point linkage dynamometer for restrainsd linkages, J. agric. Engng Res (1966) 11 (1) 33-37. 